\title{
Growth Factors in Developed Countries: A 1960-2019 Growth Accounting Decomposition
}

\author{
Gilbert Cette $^{1,2}$ - Aurélien Devillard ${ }^{2} \cdot$ Vincenzo Spiezia $^{3}$
}

Accepted: 17 September 2021 / Published online: 28 October 2021

(c) Association for Comparative Economic Studies 2021

\begin{abstract}
Using a new and original database, our paper contributes to the growth accounting literature with three original aspects: First, it covers a long period from the early 60's to 2019, just before the COVID-19 crisis; second, it analyzes a large set of economies (30 plus the Euro Area) at the country level; finally, it singles out the growth contribution of information and communications technologies (ICTs) capital as well as robots. Our findings show that the main drivers of labor productivity growth over the whole 1960-2019 period appear to have been education, total factor productivity (TFP), non-ICT and non-robot capital deepening. The relative contribution of ICT capital is found to be declining from the mid-2000s, although our country-level economy dataset does not make it possible to estimate the TFP contribution of ICTs. The contribution of robots to productivity growth through capital deepening and TFP appears to be significant in Germany and Japan in the sub-period 19751995, in France and Italy in 1995-2005, and in several Eastern European countries in 2005-2019. Our findings also confirm the slowdown in TFP in most countries from at least 1995 onwards. This slowdown is mainly accounted for by a decrease in the contributions of non-ICT non-robot capital deepening and TFP.
\end{abstract}

Keywords Growth $\cdot$ Productivity $\cdot$ ICTs $\cdot$ Robots

JEL Classification $\mathrm{O} 31 \cdot \mathrm{O} 33 \cdot \mathrm{O} 47$

Gilbert Cette

gilbert.cette@neoma-bs.fr

http://www.gilbertcette.net/

Aurélien Devillard

devillardaurelien@gmail.com

Vincenzo Spiezia

vincenzo.spiezia@oecd.org

1 Banque de France, 31 rue Croix des Petits Champs, 75049 Cedex 01 Paris, France

2 NEOMA Business School and Banque de France, Paris, France

3 OECD, Paris, France 


\section{Introduction}

Since the seminal analyses from Solow (1956, 1957, 1959 and 1962), growth accounting is the most widely used approach to measure the contribution of factors to productivity growth. Over the last decades, this approach has been used to evaluate the contribution of information and telecommunication technologies (ICTs) to growth. It consists in decomposing the growth of value added per hour worked (labor productivity) into the growth of ICT capital and non-ICT capital per hour worked, based on a set of input-specific elasticities. ${ }^{1}$

Early studies on the impact of ICTs on productivity yielded largely inconclusive results. The well-known Solow paradox for which "computers are visible everywhere except in productivity statistics" summarizes the state of art in the early 1990s. The lack of correlation between ICT investment and productivity growth was mostly due to incorrect measurement of ICT capital prices and quality. Significant improvements in the measurement of ICT capital (OECD, 2001 and 2009) have opened the way to a new stream of analysis on the growth effects of ICTs. According to OECD (2019), the yearly contribution of ICT capital to labor productivity in a set of 23 OECD countries over 1995-2017 ranged between 0.66 percentage points a year in New Zealand to 0.25 percentage points in Finland. The average yearly contribution, however, decreased from 0.42 percentage points in 2001-2007 to 0.25 percentage points in 2010-2017.

A new paradox, however, has appeared over the last two decades: While ICTs, robots and new productivity-enhancing digital technologies continue to diffuse at a sustained rate, productivity growth has slowed down in all advanced economies. This paradox has not yet received any consensual explanation so far (for a literature review, see Bergeaud et al. 2019). Gordon and Sayed (2020) observe a difference between US and Europe: The productivity slowdown appears from the mid-2000s in the US after a short revival during the decade mid-1990s to mid-2000s, and from the mid-1970s in Europe, and "as a result, the story of US productivity growth since the mid-1970s has been one of slow-fast-slow over the three intervals divided at 1995 and 2005, in contrast to a two-step deceleration in Europe."

The aim of this study is to analyze such a paradox of productivity slowdown in the age of the emerging digital economy. By developing a new database, it contributes to the growth accounting literature with three original aspects: First, it covers a long period from the early 60's to 2019, just before the COVID-19 crisis; second, it analyzes a large set of economies (30 plus the Euro Area) at the country level; finally, it singles out the growth contribution of ICT capital as well as robots, the latter being bundled with non-ICT capital in the System of National Accounts (SNA).

The original database for our analysis is built for the total economy and includes GDP, hours worked, ICT and non-ICT capital, the number of robots and educational level. Several sources were used to build this database, based on some common assumptions and according to a harmonized methodology for all countries.

\footnotetext{
1 The opinions expressed in this article are those of the authors and do not necessarily reflect those of the Banque de France, the OECD or its member countries.
} 
Our growth accounting approach shows that the main drivers of labor productivity growth over the whole 1960-2019 period appear to be education, TFP and nonICT, non-robot capital deepening. The overall contribution of ICT capital is found to be declining from the mid-2000s, although our total economy dataset does not make it possible to estimate the TFP contribution of ICT, for instance, from ICTproducing industries. The contribution of robots to productivity growth through capital deepening and TFP appears to be significant in Germany and Japan in the sub-period 1975-1995, in France and Italy in 1995-2005, and in several Eastern European countries in 2005-2019. Our findings also confirm the slowdown in TFP in most countries from at least 1995 onwards. This slowdown is mainly accounted for by a decrease in the contributions of non-ICT non-robot capital deepening and TFP.

The paper is organized as follows. Section 2 provides a brief review of previous studies. Section 3 presents the data and the methodology of the analysis. Section 4 examines the main trends in ICT capital and robots. The findings of the growth accounting analysis are presented in Sect. 5, while Sect. 6 concludes.

\section{A Review of Previous Studies}

Since the early 2000s, numerous studies have highlighted the significant contribution of new technologies to productivity growth. Focusing on the most influential among these studies, their main results can be summarized as follows: (i) the contribution of ICT capital to productivity growth became significant in the 1980s, increased until the early 2000s and became stable or even decreased afterward; (ii) large advanced economies are lagging behind the US in terms of ICT capital deepening and ICT contribution to productivity growth; and (iii) much of the effect of ICTs on productivity was channeled through spillovers to TFP growth rather than through capital deepening.

Jorgenson and Stiroh (2000) apply Jorgenson's production possibility frontier to explain productivity growth in the US after 1995. They find that the fall in ICT prices and the increase TFP were the main factor accounting for higher growth in average labor productivity in 1995-99. Based on a Solow-like growth accounting model, Oliner and Sichel $(2000,2002)$ find out that the contribution of ICT capital in the US increased between the periods 1974-95 and 1996-99 and that TFP growth also increased by $40 \%$ in the period 1996-99. Byrne et al. (2013) have updated this analysis, showing that since 2004 , ICTs have continued to make a significant contribution to US labor productivity growth, though it is no longer providing the boost that it did from 1995 to 2004. Based on a sample of nine OECD countries, Colecchia and Schreyer (2002) find that ICT contributed between 0.2 and $0.5 \%$ points per year to economic growth over 1980-2000, with the largest effects in the US followed by Australia, Finland and Canada. Using US producer price indices as a deflator for ICT investment, Oulton (2002) finds that the ICT contribution to GDP growth in the UK increased from $13.5 \%$ in $1979-89$ to $20.7 \%$ in $1989-98$. ICTs accounted for $55 \%$ of capital deepening during the period 1989-98 and 90\% in the period 1994-98. Crepon and Heckel (2002) estimate that over the period 1987-98, 
ICTs accounted for $0.7 \%$ points of the yearly value-added growth in France, 0.3 points from capital deepening and 0.4 points from TFP growth in ICT-producing industries. Van Ark et al. (2002) analyze the different impacts of ICTs on productivity between the US and Europe over the period 1980-2000. They find that while the pattern of ICT diffusion in Europe has not been much different from that in the US, EU countries started from much lower stocks of ICT capital. As a result, the contribution of ICTs to productivity growth has been lagging behind the US. O'Mahony and Vecchi (2005) estimate the impact of ICT capital on output growth using a dataset of US and UK non-agricultural market industries. Pooled estimates show a positive and significant return of ICT capital on output growth, above the prediction from growth accounting. Individual countries' estimates suggest a larger long-run impact in the US than in the UK. Timmer et al. (2010) provide a detailed analysis of the sources of growth from a comparative industry perspective. Their findings suggest that Europe's slow growth is the combined result of a severe productivity slowdown in traditional manufacturing and low ICT investment in market services. Spiezia (2012) estimates that the contribution of ICT investments to value-added growth in the business sector over 1995-2007 varied from 1.0\% a year in Australia to $0.4 \%$ a year in Japan. ICT-producing industries accounted for no less than twothirds of TFP growth in Germany, Slovenia and the UK, about $60 \%$ in the US and just below 50\% in France and the Netherlands. Cette et al. (2015) show that the Euro area, Canada, the UK and Japan are lagging behind the US in terms of ICT diffusion that in these countries, ICT contribution to growth has stopped to increase or have even has decreased from the early 2000s. Using industry-level data, Gordon and Sayed (2020) find that in 1995-2005, sustained productivity growth in the US was driven by ICT-intensive industries producing market services and computer hardware, whereas an aggregate of Western European countries included in the analysis (the EU-10) experienced a growth slowdown due to a paucity of ICT investment, a failure to capture the efficiency benefits of ICT, and performance shortfalls in specific industries including ICT production, finance-insurance, retail-wholesale, and agriculture. After 2005, both the US and the EU-10 suffered a growth slowdown, indicating that the benefits of the ICT revolution were temporary.

Several analyses as, for instance, O'Mahony and Vecchi (2005) emphasize the complexity of the link from technology to productivity. To leverage ICT investment successfully, firms must typically make large complementary investments and innovate in areas such as business organization, workplace practices, human capital and intangible capital.

The role of intangible capital and its interaction with ICT concerning its impact on productivity is highlighted in numerous analyses. Corrado et al. (2009) incorporate intangible assets into a macrogrowth accounting framework. The inclusion of intangibles results into a lower contribution of TFP to labor productivity as well as a larger contribution of capital deepening and other factors typically associated with the knowledge economy. Corrado et al. (2020) develop a theoretical framework to analyze the relationship among intangibles, innovation, and productivity by building a Jorgenson-like model of economic growth. They also provide empirical evidence for the US plus a sample of European countries. They show that the intangible capital recovered faster than that of tangible capital after the Great Recession, and that 
there is a positive relationship between intangible and ICT capital growth and TFP growth, whereby the decrease in intangible capital growth explains the decline of TFP growth more in the US than in Europe.

The increasing contribution of robots to productivity growth is shown in a growing literature, and, for instance, on French firm-level data by Acemoglu et al. (2020) or by Graetz and Michaels $(2015,2018)$ on a country-industry dataset. But even if the impact of robot adoption appears large at the firm level, these analyses show that it stays small and, for instance, far below that of the ICT at the country level.

The productivity slowdown observed in developed countries over the last decades (see Bergeaud et al. 2016, 2017), and its explanatory factors are analyzed also in a growing literature. Through growth accounting approaches, Bergeaud et al. (2018) show that the end of the diffusion of innovations linked to the second industrial revolution and the end of the long increase in the average education level of the working age population contribute only partly to the productivity slowdown. And Bergeaud et al. (2019) show that the general decrease in real interest rates contributes also but only in a small way to the productivity slowdown. Burda and Severgnigni (2009) propose a TFP evaluation using a growth accounting approach over the period 1994-2004 on 30 European countries. They distinguish labor and capital as production factors, and they show that new market economies of Central and Eastern Europe benefit from a TFP acceleration on the period, whereas the other European countries suffer from a TFP slowdown. According to them, market regulations would play a large role to explain TFP behavior. Inklaar et al. (2020) analyze the supply factors of the European growth compared to the US between 1995 and 2015. They show that both in Europe and in the US, ICTs have significantly contributed to productivity growth, but they admit not to be able to explain the general productivity slowdown. It seems to them that we are still « in the midst of the transition from the Old Digital Economy (which was characterized by the introduction of the PC in people's lives and business processes, the rise of the Internet, and the beginning of the e-commerce) to the New Digital Economy (which is characterized by the change toward mobile, ubiquitous access to the Internet, the storage and usage of data, and advances in artificial intelligence and robotics)».

Esfahani et al. (2020) provide a different perspective on productivity and the evolution of the world productivity frontier, showing that "the center of gravity of technological progress has shifted more towards emerging economies" over 1996-2014 and that "changes in the misallocation of global productive resources account for a substantial part of increases and fluctuations in global productivity." Overall, the general productivity slowdown has not yet received a consensual explanation.

\section{Data and Growth Accounting Methodology}

\section{Data}

To carry out our growth accounting evaluation, we need data concerning GDP, hours, capital and user cost of capital, education and robots. Except for some which are mentioned to be built on a longer period, all data are built from 1951 to 2019. 
For data in constant price, the base is 2015. These data are built for each of the 30 countries of the analysis: Australia, Austria, Belgium, Canada, Czech Republic, Denmark, Estonia, Finland, France, Germany, Greece, Hungary, Ireland, Israel, Italy, Japan, Latvia, Lithuania, Luxembourg, Mexico, the Netherlands, Norway, New Zealand, Portugal, Slovakia, Slovenia, Spain, Sweden, the United Kingdom and the US. The Euro Area has been reconstituted from 1960 onwards, aggregating Germany, France, Italy, Spain, the Netherlands, Belgium, Austria, Finland, Greece, Ireland, and Portugal, these 11 countries accounting together for $97 \%$ of the Euro Area GDP in 2018.

Data concerning the GDP in current value come from several databases: BEA for the USA, Eurostat, OECD, Penn World Tables 9.1, and the UN. Sources concerning the GDP deflator are the BEA for US, INSEE for France, Eurostat, OECD and Penn World Table 9.1 for all other countries. It has been extrapolated from 1950 to 1989 for Czech Republic, Estonia, Lithuania, Latvia, Slovakia, Slovenia and to 1969 for Hungary, using the growth rate of a similar country. GDP in constant 2015 value results from the ratio of the GDP in current value by the GDP deflator.

The number of hours worked is the average annual working time per worker multiplied by the employment. The sources of these two indicators are the LongTermProductivity database (LTP hereafter), the National Accounts of OECD Countries (2020), OECD and The Conference Board Total Economy Database (The Conference Board, 2020), TED (Total Economy Database). The LTP database contains data from 1950 for the following countries: Australia, Austria, Belgium, Canada, Germany, Denmark, Spain, Finland, France, the UK, Greece, Israel, Italia, Japan, Mexico, the Netherlands, Norway, New Zealand, Portugal, Sweden and the US. For the other countries, we use OECD and TED. The working time per worker is extrapolated for Czech Republic, Estonia, Hungary, Israel, Lithuania, Luxembourg, Latvia, Slovakia and Slovenia from 1950 to 1994 at the latest using the growth rate of a similar country.

The total stock of capital in constant price is computed with data from the LTP database for the countries available in this base, and for the other countries, we use the Penn World table and Ameco. In the LTP database, the stock of capital in constant price is built separately for equipment and buildings through a perpetual inventory model (PIM hereafter), the yearly depreciation rates being $10.0 \%$ for equipment and $2.5 \%$ for buildings and being assumed to be constant across time and space (see Bergeaud et al. 2016 and 2017).

The ICT capital stock in constant price is built through a PIM applied on investment in constant price data, for each of the three ICT products: hardware, software and telecommunication equipment. For telecommunication equipment, the initialization starts in 1931, and it starts in 1951 for the two other products. As in previous analyses, the yearly depreciation rates are 0.3 for hardware and software and 0.15 for telecommunication equipment (see, for instance, Cette et al. 2015, or 2017). The investment in constant price is calculated by the ratio of the investment in current price and the corresponding deflator. Data concerning ICT investment in current price were provided by the OECD in 3 series, respectively, revised in 1993, before 2019 and after 2019 for each of the three ICT products with partially available data. From 1950 (1930 for telecommunication equipment) to 1959, we build data for all 
countries supposing that the investment rate (investment in value divided by the GDP in value) is constant. This method is used on a longer period, until 2004 at the latest, for Czech Republic, Estonia, Hungary, Israel, Lithuania, Latvia, Mexico, Slovakia and Slovenia. For Austria, Portugal and Greece, we also build data from 1960 to 1994: we compute the investment rate of the country in 1995, and we suppose that it follows the evolution of the investment rate of a similar country for the past years, respectively, Germany, Spain and Italy.

Concerning the deflators of ICT investment, for each of the three ICT product, we use for the US the one computed by the Bureau of Economic Analysis (BEA). For the other countries, and as in numerous other analyses (as, for instance, the same analyses than those mentioned before), we use a method suggested by Schreyer (2000): It supposes that the relative price ratio of investment to GDP is the same than in the USA.

Nominal long-term interest rates correspond to sovereign 10-year bonds. The primary source of data is the OECD Main Economic Indicators (OECD, 2018) which we backdate using the Macrohistory database constructed by Jordà et al. (2019), International Financial Statistics, Eurostat and Ameco databases for Austria, Czech Republic, Estonia, Greece, Hungary, Ireland, Israel, Lithuania, Luxembourg, Latvia, Mexico, New Zealand, Slovakia and Slovenia, we build data using the nominal interest rate of a reference country, and we add the difference of growth rate of the GDP deflator of both countries.

Education corresponds to the average number of years of schooling of the population aged 25 and more. We use for that series of educational attainment provided by van Leeuwen and van Leeuwen-Li (2014) updated by Bergeaud et al. (2018), with data from the UNESCO and the Penn World Table 9.1.

The source of data on robots is the World Robotics Industrial Robots statistics compiled by the International Federation of Robots (IFR), covering installations and the operational stocks of robots from 1983 to 2019, with partially available data. We consider the industrial robots, corresponding to the definition of the International Organization for Standardization (ISO 8373:2012): an "automatically controlled, reprogrammable multipurpose manipulator programmable in three or more axes."

IFR collects data on robot installations by country, industry and application from nearly all industrial robot suppliers worldwide. It complements this information with data from several national robot associations, including Korean Association of Robot Industry (KAR), the Japanese Robot Association (JARA), the Robotic Industries Association (RIA) providing data on North America and the Chinese Robot Industry Alliance (CRIA). Prior 2004, country reports relied exclusively on data of national robot associations.

The operational stock of robots measures the number of robots currently deployed. JARA calculates and provides this figure for Japan. For all other countries, IFR calculates the operational stock assuming an average service life of 12 years with an immediate withdrawal from service afterward (see IFR, 2001 for a discussion about the length of the service life).

To complete the IFR database and extend the series back to 1960, we estimated the stock of operational robots based on an OLS regression on the stock of each of the three ICT capital products (hardware, software and telecommunication), with 
fixed effects for countries and a common trend. This method has been privileged after robustness tests made with other regressions. ${ }^{2}$

\section{Growth Accounting Methodology}

The contribution to labor productivity growth of the capital deepening in total capital and in each ICT component is estimated by applying the growth accounting methodology suggested by Solow $(1956,1957) .{ }^{3}$ For each of these four scopes (the index is excluded for to simplify notations), the contribution of capital to labor productivity growth in year $t$, noted as $C K_{t}$, is evaluated through the following relation:

$$
C K_{t}=\alpha_{T, t} .\left(\Delta k_{t-1}-\Delta n_{t}-\Delta h_{t}\right)
$$

where $K_{t-1}$ corresponds to the capital installed at the end of year $t-1, N_{t}$ refers to total employment in year $t$, and $H_{t}$ designates the average annual hours worked per person per year $t$. The notation of the variables in lowercase corresponds to their natural log $(x=\ln (X))$, and the growth rate of a variable is approximated by the variation of its logarithm. The $\Delta$ symbol refers to the variation of a variable $\left(\Delta X_{t}=X_{t}-X_{t-1}\right)$.

Concerning the global stock of capital, the coefficient $\alpha_{T, t}$ is assumed to be constant over time and the same in all countries, and equal to $0.3\left(\alpha_{T, t}=0.3\right){ }^{4} \mathrm{~A}$ decrease in the labor share over time means that the coefficient $\alpha_{T, t}$ would increase. But the literature is not consensual concerning such a decrease in the labor share, and a long-term stability seems to be a reasonable hypothesis (for a literature survey and some evaluations see Cette et al., 2020). In the proposed growth accounting approach, the choice of another value of this parameter would change two lines of the growth decomposition: the contributions of the "non-ICT capital and the nonrobot capital" in the capital deepening process and the TFP "residual." The consequence of a higher (lower) value of $\alpha$ would be (in absolute value) a higher (lower) contribution of the "non-ICT capital and the non-robot capital" and a lower (higher) contribution of the "residual." But it appears that our results are robust to this calibration of $\alpha$ and remain roughly stable for other realistic values (see Bergeaud et al. 2016, 2018). This stability was here also verified.

Concerning each of the three ICT components, the coefficient $\alpha_{T, t}$ is the Törnquist index of the coefficient $\alpha_{t}$ :

$$
\alpha_{T, t}=\left(\alpha_{t}+\alpha_{t-1}\right) / 2
$$

\footnotetext{
2 Detailed results of these econometric estimates are available upon request from the authors.

3 This decomposition assumes that the production function can be approximated by a Cobb-Douglas function with constant returns to scale.

4 As it is the case here concerning the three ICT capital components, it is generally assumed that production factors are remunerated at their marginal productivity (at least over the long term, which is the horizon of the study), which means that it is possible to estimate factor elasticities on the basis of the share of their remuneration (cost) in total income (or total cost). Concerning the global stock of capital, given that labor costs (wages and related taxes and social security contributions) represent roughly two-thirds of income, it is simply assumed here that $\alpha=0.3$.
} 
Table 1 Estimated elasticities of labor productivity to robots. Source: Based on Graetz and Michaels (2015), Tables A7 (2), A6 (2) and 6 (2).

\begin{tabular}{llll}
\hline & & $\Delta \ln (\mathrm{VA} / \mathrm{H})$ & $\Delta \ln (\mathrm{TFP})$ \\
\hline (1) & $\Delta(\mathrm{R} / \mathrm{H})$ & 0.144 & \\
$(2)$ & $\Delta$ percentile of $(\mathrm{R} / \mathrm{H}) / 100$ & 0.873 & \\
(3) & $\Delta$ percentile of $(\mathrm{R} / \mathrm{H}) / 100$ & & 0.663 \\
\hline
\end{tabular}

$\mathrm{R}$ stands for number of robots, $\mathrm{H}$ stands for million hours worked, VA per value added and TFP for total factor productivity. All estimates are instrumental variables (IV).

The above elasticity being estimated by Graetz and Michaels (2015) on the set of sectors using robots, we have weighted its effect by the share of those sectors in the total value added in each country. Robot-using industries include ISIC Rev.4 01-03, 05-09, 10-32, 35-39, 41-43 and 72 .

The coefficient $\alpha_{t}$ corresponds to the share of the capital remuneration (remember that this is calculated for each ICT product) in the GDP:

$$
\alpha_{t}=\left(C_{t} \cdot K_{t-1}\right) /\left(P Q_{t} \cdot Q_{t}\right)
$$

where $C_{t}$ corresponds to the user cost of capital, $K$ refers to the capital stock in volume, $P Q$ corresponds to the GDP deflator, and $Q$ refers to GDP in volume.

The user cost of capital $C$ is calculated employing the relation proposed by Jorgenson (1963):

$$
C_{t}=P_{t} \cdot\left(i_{t}+\delta+\Delta p_{t}\right)
$$

where $P$ corresponds to the investment price of the ICT product, $i$ refers to the longterm nominal interest rate, and $\delta$ designates the assumed invariant depreciation rate of the ICT product.

Concerning the impact of education on labor productivity, we use here the results from Bergeaud et al. (2018) estimated on a panel of 17 developed countries, which are totally consistent with those from other analyses as, for instance, Barro and Lee (2010), Soto (2002) or Krueger and Lindahl (2001). It corresponds to a calibration of a $5 \%$ labor productivity increase for one more year of average schooling. ${ }^{5}$ It is of course a huge simplification to assume that this parameter is stable over time and is the same in the different countries.

Concerning the impact of robots on labor productivity, we use here the results from Graetz and Michaels (2015) estimated on a panel of 14 developed countries, which seem consistent (as far as the comparison is possible) to the ones of Acemoglu et al. (2020) estimated on a panel of French firms. The relevant set of estimates by Graetz and Michaels (2015) are shown in Table 1. (1) shows the estimated

\footnotetext{
5 It is interesting to add some details about what this elasticity means. From the neoclassical framework, we indeed have: $Y=T F P^{\prime} \cdot K^{\alpha} \cdot L^{1-\alpha} e^{(1-\alpha) \theta \cdot S}$ where $Y$ is the output and $s$ is the average number of schooling years. The estimated value of $\theta$ is often close to 0.7 (see Bergeaud et al., 2018 for a survey). Considering that we assume $\alpha=0.3$, it means that for one more year of average schooling, labor productivity increases by $5 \%$.
} 


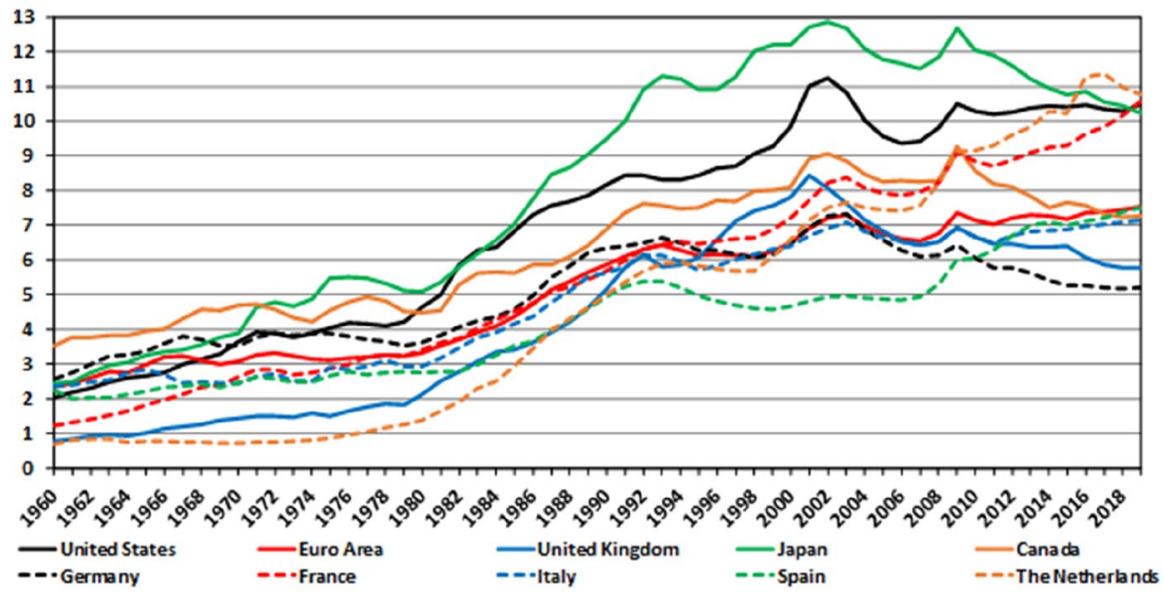

Fig. 1 ICT Capital Coefficient, 1960-2019 Ratio of ICT capital stock to GDP in current prices, \%. Source: Authors' calculations

elasticity of labor productivity to the number of robots per million hours worked (0.144). (2) shows the estimated elasticity of labor productivity to percentile changes in the number of robots per million hours worked (0.873). (3) shows the estimated elasticity of TFP to percentile changes in the number of robots per million hours worked (0.663). As the three elasticities have been estimated based on the same specification and the same sample, (2) and (3) together imply that $76 \%$ (i.e.: $0.663 / 0.873$ ) of the estimated contribution of robots to labor productivity occurs via TFP, while the remaining $24 \%$ is accounted for by capital deepening. Applying this decomposition to the elasticity in (1), we obtain our coefficients to estimate the contribution of the number of robots per million hours worked to labor productivity via TFP $(0.76 * 0.144=0.1044)$ and via capital deepening $(0.24 * 0.144=0.0396)$. Based on those estimates, we are able to single out the contribution of robots to labor productivity growth through the two channels: capital deepening and TFP. Robots are included in the stock of non-ICT capital, their ICT components being intermediate consumption of robot producers (see Cette et al. 2019).

\section{ICT and Robot Diffusion}

\section{ICT Diffusion}

The ICT diffusion is here measured as the ICT capital coefficient in current prices, which corresponds to the ratio (in percentage) of the ICT capital and the GDP in current prices.

The evolution of the ICT capital coefficient over the period 1960-2019 seems to follow the same type of path in the ten largest countries (or area) of our dataset (Fig. 1). We can distinguish three phases. First, a slow increase during two decades, until the early 1980 s. This phase corresponds to the progressive start of the 
ICT diffusion. Second, a rapid increase during the two following decades, until the beginning of the current century. This phase corresponds to the golden age of ICT diffusion and to the strong development in the use of these productive technologies. Third, a stabilization or even a decrease in some countries such as the UK, Japan, Canada or Germany, during the last two decades. The ICT capital coefficient continues to increase during this third sub-period in a few countries such as France, Spain and the Netherlands.

In the main countries and areas, the ICT capital coefficient reaches a maximum at the beginning of the 2000s. The peak at the beginning of the 2000s signifies a spurred investment effort associated with the fear of Y2K. The stability of the nominal ICT capital coefficient since the beginning of the 2000s has already been observed by Cette and Lopez (2012) or Cette et al. (2015). Our study confirms this result and shows that the stagnation persists during and after the Great Recession: The diffusion of ICT as a factor of production appears to stabilize for about two decades. The ICT capital coefficient in current prices stabilizes at different levels depending on the country. ICT diffusion in the US settles at a level equivalent to Japan, France and the Netherlands, and higher than in the other countries. The lag in the pace of ICT diffusion is considerable for some countries. By 2019, the US has an ICT capital coefficient that is $40 \%$ higher than for the Euro Area and Canada and even $80 \%$ higher than for the UK. Earlier analyses support these cross-country differences in ICT diffusion. ${ }^{6}$

Numerous studies provide explanations for these international differences in ICT diffusion, including the level of post-secondary education among the working age population as well as labor and product market rigidities. For example, an efficient use of ICT requires a higher degree of skilled labor than the use of other technologies. The required reorganization of the firm for effective ICT adoption can be constrained by strict labor market regulations. Moreover, low levels of competitive pressure resulting from product market regulations can reduce the incentive to exploit the most efficient production techniques. A large number of empirical analyses have confirmed the importance of these factors. ${ }^{7}$ Quite simply, the US benefits from a high level of ICT diffusion because of a high level of post-secondary education among the working age population and few restrictive product and labor market regulations.

The stability of the ICT capital coefficient in current prices from the early 2000s is consistent with a continuous increase of the ICT capital coefficient in constant prices, considering the decrease of the ICT price relative to the GDP price by $2 \%$ on average per year from 2000 to 2019 . But it has not the same meaning in terms of ICT diffusion.

ICT capital coefficients differed significantly in 2019 over our complete set of 31 countries and areas (Fig. 2). It is by far the highest in Sweden, with a capital

\footnotetext{
${ }^{6}$ See for instance van Ark et al. (2008), Timmer et al. (2011), Cette and Lopez (2012) or Cette, Clerc and Bresson (2015).

7 See Aghion et al. (2009), Guerrieri et al. (2011) and Cette and Lopez (2012) who use country-level panel data, as well as Cette et al. (2013) who employ sectoral-level panel data.
} 


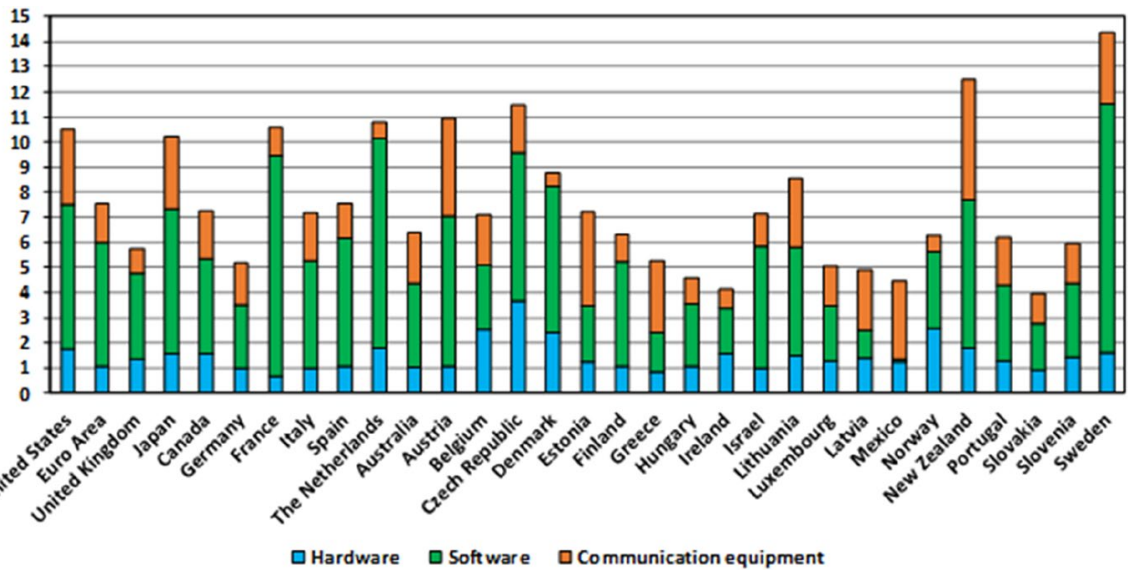

Fig. 2 ICT Capital Coefficient, 2019, Ratio of ICT capital stock to GDP in current prices, \%, Source: Authors' calculations

coefficient superior to $14 \%$, the following country being New Zealand, 2pp below. The ICT capital coefficient is superior to $10 \%$ in 8 countries: Sweden, New Zealand, Czech Republic, Austria, the Netherlands, the United States, France and Japan. In contrast, it is inferior to $5 \%$ in five countries: Lithuania, Hungary, Ireland ${ }^{8}$, Mexico and Slovakia. Other countries, including the Euro Area considered as a whole, are in an intermediate situation. The three ICT products (hardware, software and communication equipment) contribute to these differences.

\section{Robot Diffusion}

Robots can now perform a wide range of tasks, with very little or no human intervention. Unlike ICTs, they are able of flexible movements in three dimensions, which were previously exclusive to human beings.

Graetz and Michael (2018) estimate that the price of industrial robots in six major developed economies (France, Germany, Italy, Sweden, the UK and the US) in 1990-2005 fell by about 50\% in nominal terms and $80 \%$ when adjusted for quality. Such a decrease has fueled rapid diffusion in robots in a number of economies.

The diffusion of robots started in the early 70s, first in Japan, followed by Germany (Fig. 3). In other countries, robot diffusion started to pick about a decade later. Japan had the highest penetration of robots in the sample until 2011, when Germany took the lead. In Japan, the number of robots per million hours worked decreased in 1998-2003 due to the crisis of the IT sector, fluctuated in 2004-2008 and decreased further in 2009-2017, following the delocalization of activities in the automobile, electrical and electronic industries.

\footnotetext{
${ }^{8}$ For Ireland, we cannot exclude that this low ICT capital coefficients could correspond more to measurement problems than to reality.
} 


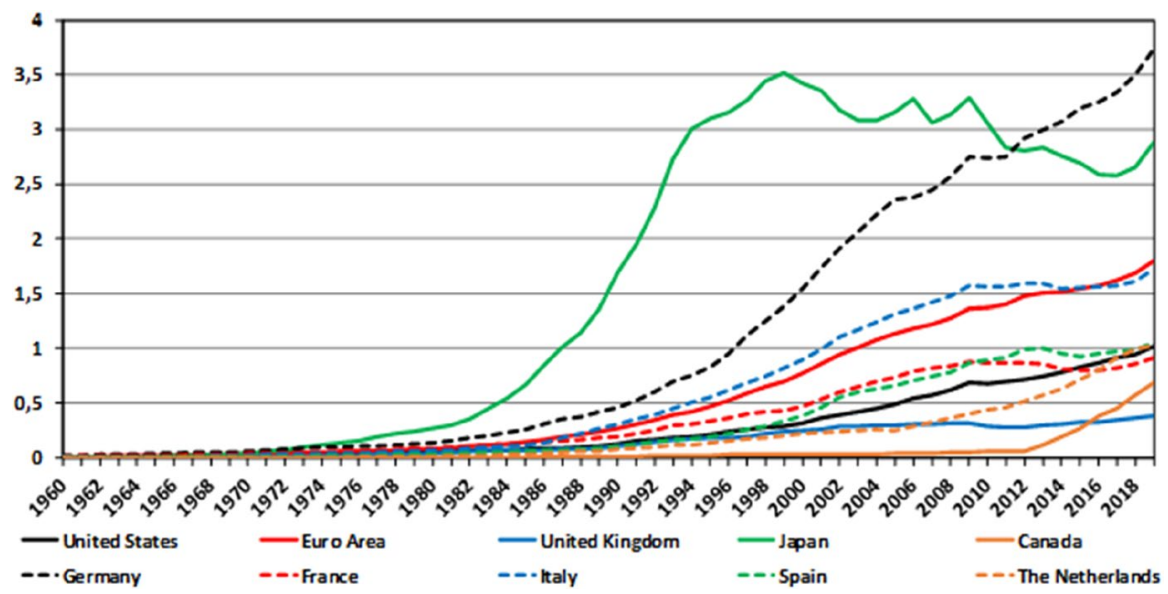

Fig. 3 Robot diffusion, 1960-2019, Number of robots per million hours worked. Source: Authors' calculations

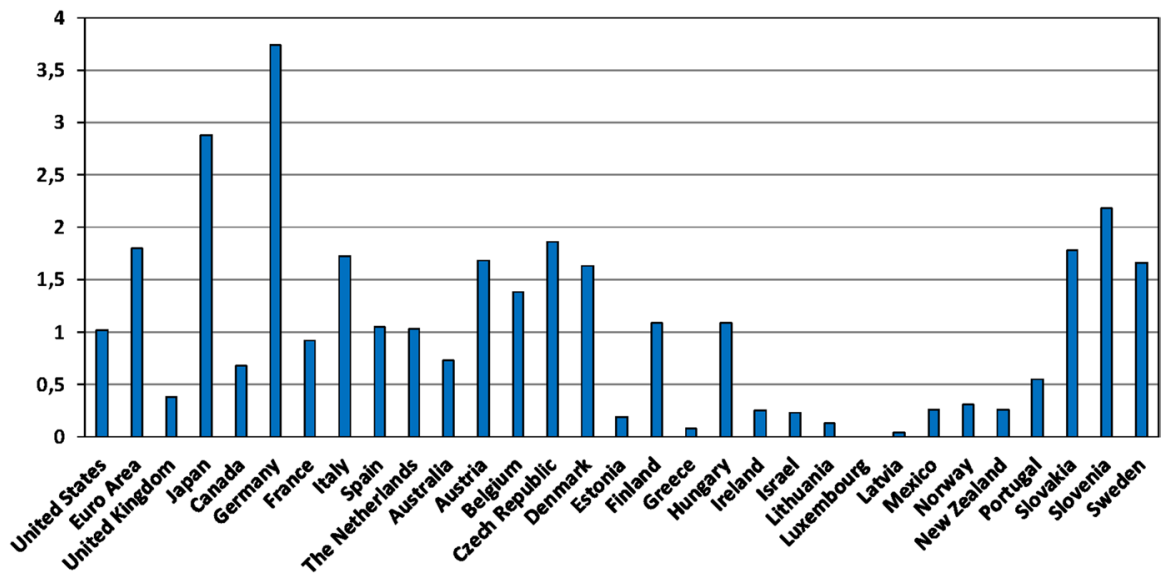

Fig. 4 Robot diffusion, 2019, Number of robots per million hours worked. Source: Authors' calculations

While penetration has been increasing steadily in other countries, the number of robots per millions of hours worked remains lower than in Germany and Japan (Fig. 4). Among them, Slovenia, the Czech Republic, Italy, Slovakia and Sweden show the highest values (above 1.5 robots per millions of hours worked).

Robots tend to be concentrated in few manufacturing sectors. Transport equipment accounts for about $45 \%$ of the world stock of robots, electronic, electrical and optical equipment for $30 \%$, rubber and plastic for $8 \%$ and metal products for between $6 \%$. Therefore, the observed patterns of diffusion also reflect countryspecific specializations.

While the effects of robots are a matter of vivid debate among economists (for instance, Brynjolfsson and McAfee, 2014; Autor, 2015; Acemoglu and Restrepo, 


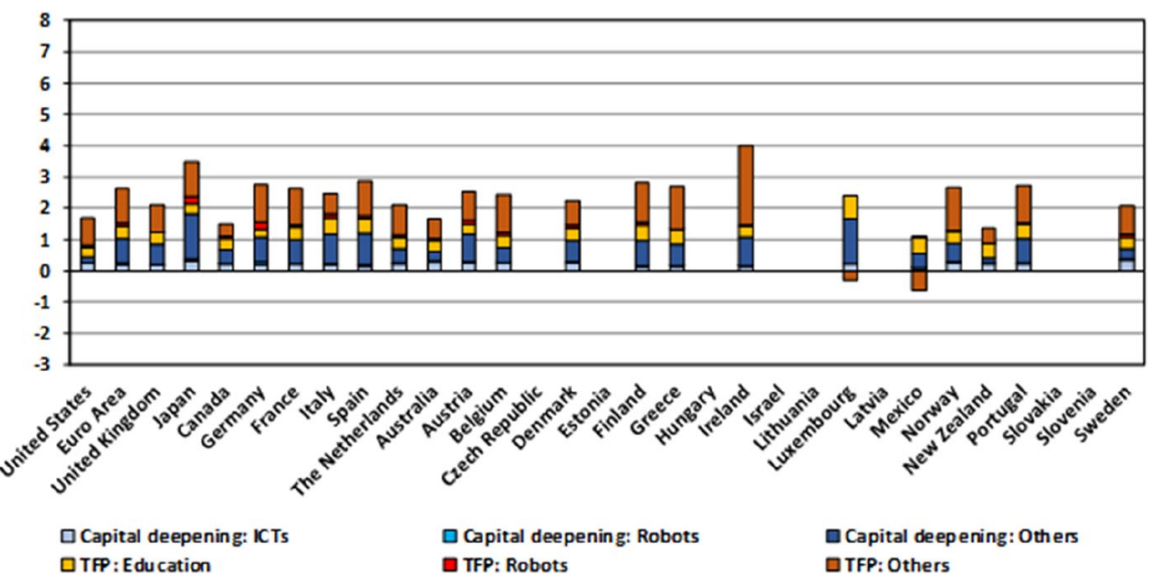

Fig. 5 Productivity growth decomposition, in pp 1960-2019, Source: Authors' calculations

2020), only a few empirical studies have looked at their impact on productivity. Among the few exceptions, Graetz and Michael (2018) found that increased robot use contributed approximately $0.36 \%$ points to annual labor productivity growth in 17 countries from 1993 to 2007 . Our findings below extend their results to a wider set of countries (30) over a longer time period (until 2019).

\section{Growth Accounting Decomposition}

The methodological section above describes how labor productivity growth can be broken down into different factors through a classical growth accounting approach. More precisely, we distinguish here between the capital deepening channel and the TFP one, and within each of these two main channels three components: ICTs, robots and others for the capital deepening one, and education, robots and others for the TFP one. For the two channels, the component 'others' corresponds to numerous implicit factors such as, for instance, technical progress (not included in ICTs and robots), institutions, or miss-measurement. This decomposition allows us to analyze the factors of productivity growth (4.1.) and the factors of the productivity slowdown (4.2.). We do not make this decomposition before 1995 and over the whole 1960-2019 period for the former communist countries ${ }^{9}$ and Israel, their data not being precise enough. The appendix presents detailed results of the growth accounting decomposition concerning the G7 countries (Canada, France, Germany, Italy, Japan, the UK and the US), the Euro Area and Spain. ${ }^{10}$

\footnotetext{
9 These countries are in our dataset the Czech Republic, Estonia, Hungary, Lithuania, Latvia, Slovakia and Slovenia. Concerning the lack of quality of Eastern European countries before the early 1990, see for instance Vonyó (2017).

10 Same tables for other countries among the 30 ones of our database are available upon request from the authors.
} 


\section{The Factors of Growth}

Over the whole 1960-2019 period, the main factors contributing to labor productivity growth were TFP, non-ICT non-robot capital deepening and education (Fig. 5). The highest average labor productivity growth rates are observed in Ireland and Japan, which can be explained by an initial low level and a catching up process. In contrast, the lowest average labor productivity growth rates are observed in the US and Canada, where initial productivity levels were high, and also in Mexico and New Zealand, which suffer from other productivity brakes: un-adapted institutions for the former and geographical isolation which increases the trade costs for the latter. Other countries are in an intermediate situation. These results are consistent with those of previous analyses (see, for instance, Bergeaud et al. 2016 and 2018) and, in particular, with the findings by Gordon and Sayed (2020) about the labor productivity behavior in the US and Europe.

We look at the factors of labor productivity growth over 4 sub-periods: $1960-1975$ before the first oil shock, 1975-1995 from the first oil shock to the starting point of the ICT main diffusion period at least in the US (Jorgenson, 2001; Jorgenson et al., 2006 and 2008), 1995-2005 being the highest ICT diffusion sub-period, and 2005-2019 the end of the period including the Great Recession (Fig. 6a-d).

It appears that the relative contribution of ICT capital deepening is small in the four sub-periods, but consistent with other evaluations (see, for instance, Timmer et al. 2010). As discussed above, this does not include the contribution of ICT-producing industries to TFP, which has been found sizeable (Byrne et al. 2013; Fernald, 2015; Gordon and Sayed, 2020). Robots' contribution to productivity growth through the two channels, i.e., capital deepening and TFP, appears to be significant in the two countries with highest robot diffusion, i.e., Germany and Japan from the sub-period 1975-1995; in France and Italy in 1995-2005 and in several other countries, mainly the former communist countries, in the last sub-period 2005-2019. Education has a permanent significant contribution to productivity growth in almost all countries. And the main contributions to productivity growth are the other factors of capital deepening and TFP. These two factors contribute globally the most and very significantly from 1975 in Ireland, and from 1995 in the countries previously communist, for the same catching up reason.

\section{The Factors of Productivity Slowdown}

Except for countries that are in a late productivity catching up process, such as Ireland and former communist countries, we observe a general and dramatic productivity slowdown (Fig. 6a-d). Figure 7 shows the sources of the slowdown observed in 28 countries in the most recent period of our analysis (2005-19) over the previous one (1995-2005). In 15 countries (Australia, Austria, Canada, Finland, France, Greece, Israel, Luxembourg, Mexico, the Netherlands, Norway, New Zealand, Sweden, the UK and the US), the slowdown was mainly accounted for by a decrease in the contribution of the component "Others" in the TFP. In eight countries (the Czech Republic, Estonia, Hungary, Japan, Latvia, Lithuania, Slovakia and Slovenia), 


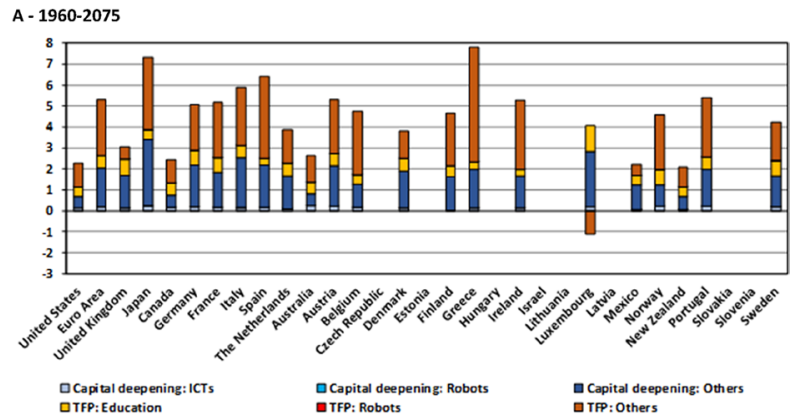

B- 1975-1995

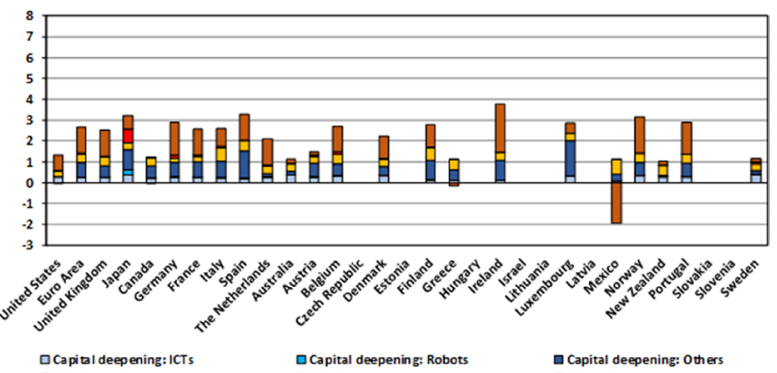

QTFP: Education $\quad$ QTFP: Robots Others

C-1995-2005
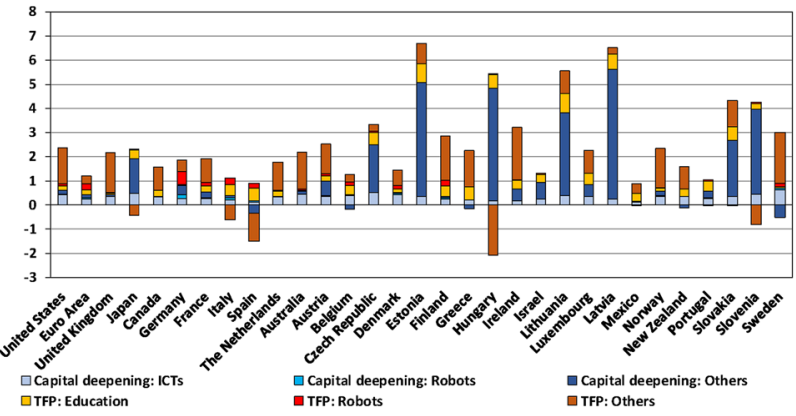

D - 2005-2019

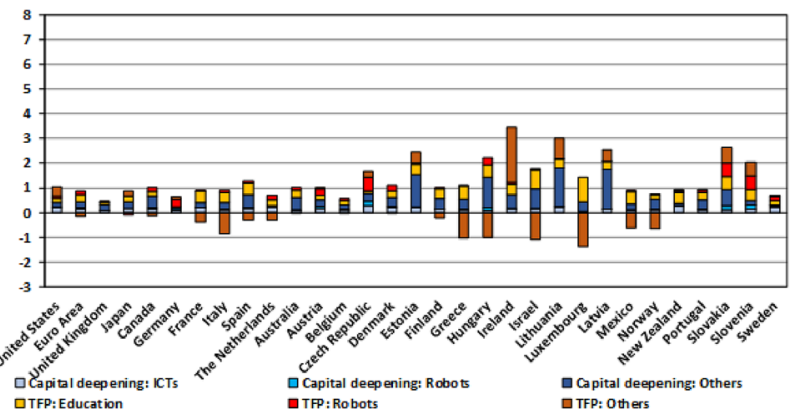

Fig. 6 Productivity growth decomposition, in pp, a 1960-2075, b 1975-1995, c 1995-2005, d 20052019. Source: Authors' calculations

称 


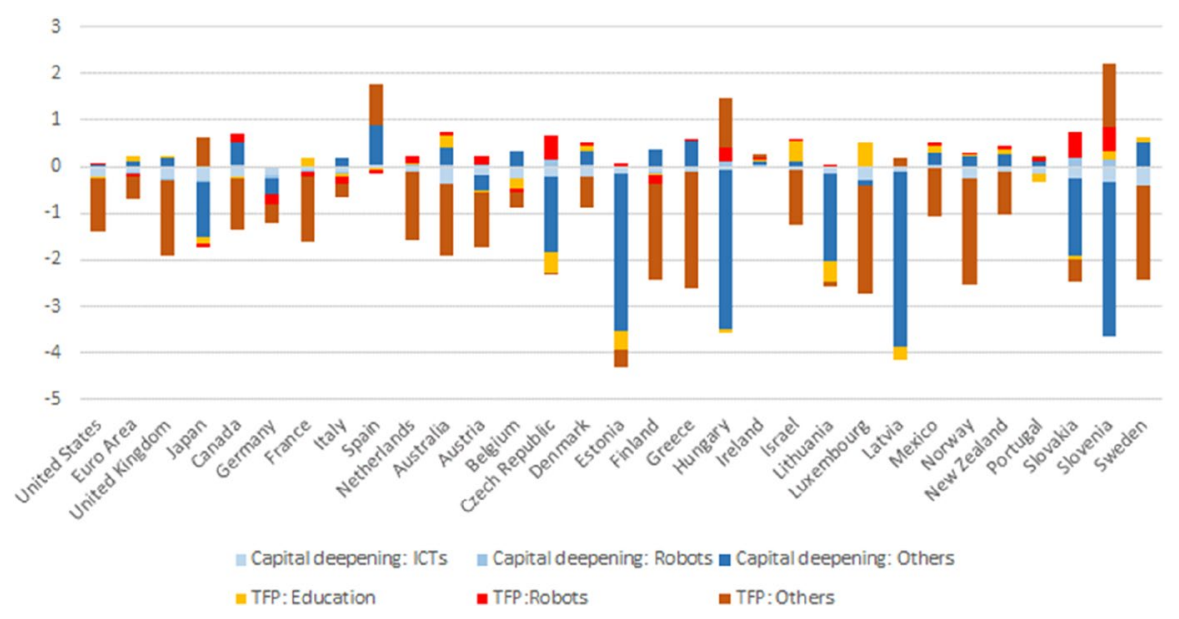

Fig. 7 Decomposition of the productivity slowdown in 2005-2019 relative to 1995-2005, in pp. Source: Authors' calculations

a decrease in the contributions of the components 'others' in the capital deepening was the main source of the observed productivity slowdown. In the remaining five countries (Belgium, Denmark Germany, Italy and Portugal), the slowdown was accounted for by a combination of different factors.

Part of the observed decline could be accounted to measurement errors of digital products and assets, although the evidence of mismeasurement remains limited (Ahmad and Schreyer, 2016; Syverson, 2016). The decline could follow from an exhaustion of the favorable impact of the Second Industrial Revolution as explained by Gordon (2016) or Bergeaud et al. (2018). The specific productivity revival in the US during the decade 1995-2005 comes, in our analysis, mainly from a TFP acceleration. As explained by Gordon and Sayed (2020), this could come from ICTs "because much of the effect of the US ICT revolution appears to have been channeled through spillovers to TFP growth rather than being limited to the capital deepening pathway." Nevertheless, productivity slowdown appears in the US from the mid-2000s, after this revival, and from mid-1970s in the other countries. The digital revolution and Third Industrial Revolution, to which are linked ICTs and robotization among other elements, are not yet the sources of a general productivity revival, even if we could expect from them a large contribution to productivity growth.

Numerous analyses have stressed that it always takes a long time for the full impact of a technological revolution to be felt in productive activity (see, for example, Brynjolfsson, McAfee, 2014; van Ark, 2016; Branstetter and Sichel, 2017). As Robert Solow famously wrote in a 1987 article in the New York Times, ${ }^{11}$ "You can see the computer age everywhere, but in the productivity statistics." This impatience suggests we have forgotten what happened in previous technological revolutions: The profound changes were only diffused gradually, and their impact on productive

$\overline{11}$ Article entitled "We'd better watch out" published in the New York Times Book Review, 12 July, 1987. 
Table 2 Average annual growth rate of ICT investment prices. Sources: Authors calculation from BEA concerning National accounts, and Byrne and Corrado (2017a, 2017b2016) concerning Byrne-Corrado. Data are updated by these authors and kindly made available to us by them.

\begin{tabular}{lllllll}
\hline & & $1960-1975$ & $1975-1995$ & $1995-2005$ & $2005-2019$ & $1960-2019$ \\
\hline \multirow{2}{*}{ Hardware } & National accounts & -19.13 & -14.83 & -16.94 & -3.92 & -13.87 \\
& Byrne-Corrado & -17.70 & -17.96 & -23.55 & -15.58 & -18.32 \\
\multirow{2}{*}{ Software } & National accounts & -0.50 & -1.18 & -2.21 & -1.26 & -1.20 \\
& Byrne-Corrado & -1.24 & -2.03 & -5.46 & -4.10 & -2.92 \\
\multirow{2}{*}{ Communication } & National accounts & 3.29 & 1.55 & -5.98 & -7.58 & -1.56 \\
Equipment & Byrne-Corrado & 0.11 & -2.09 & -9.29 & -7.58 & -4.13 \\
\hline
\end{tabular}

performance was not felt until decades later. David (1990) has shown that between 50 and 60 years passed between the invention of a working electric dynamo in 1868 and its full exploitation in production (in the 1920s to 1930s).

As Van Ark (2016) or Inklaar et al. (2020) say, the current pause in the productivity gains from the Third Industrial Revolution could in fact be a period of transition between the creation and installation of new technologies and their full deployment. As with previous technological revolutions, notably the use of electric power, this deployment phase will take time and will require major changes to our institutions and to our methods of production and of management.

\section{An Alternative Evaluation of the ICT Capital Deepening Contribution to Labor Productivity Growth}

As discussed above, ICT investment prices used in this analysis are drawn from the US national accounts, based on the assumption that the price ratio of ICT investment to GDP in all countries is the same as in the US. Some analyses have stressed that the US national accounts would underestimate the decrease of ICT prices, more particularly in the recent period. This price decrease underestimation is observed for hardware and its more technological components such as semiconductors (concerning semiconductors see, for instance, Byrne et al. ( 2015).

Byrne and Corrado (2017a; b2016) have developed a set of ICT price indexes based on a more accurate measurement of ICT quality improvement. Over the whole period 1960-2019, the average annual growth rate of their ICT prices indexes is below that of the equivalent indexes in the US national accounts by about $4.5 \mathrm{pp}$ for the hardware, $1.7 \mathrm{pp}$ for the software and 2.6pp for the communication equipment (Table 2). Concerning the hardware, this gap increases over time and is about 11.4pp over the period 2005-2019. Such an under-evaluation of the ICT price decrease has no large direct impact on the evaluation of the labor productivity change. ${ }^{12}$ However,

\footnotetext{
12 There is an indirect labor productivity measurement impact as this over-evaluation of ICT investment price changes means an under-evaluation of the output from industries producing these investment products and consequently of the productivity growth. Nevertheless, as these industries represent a small part of the economy, this indirect impact should be small.
} 


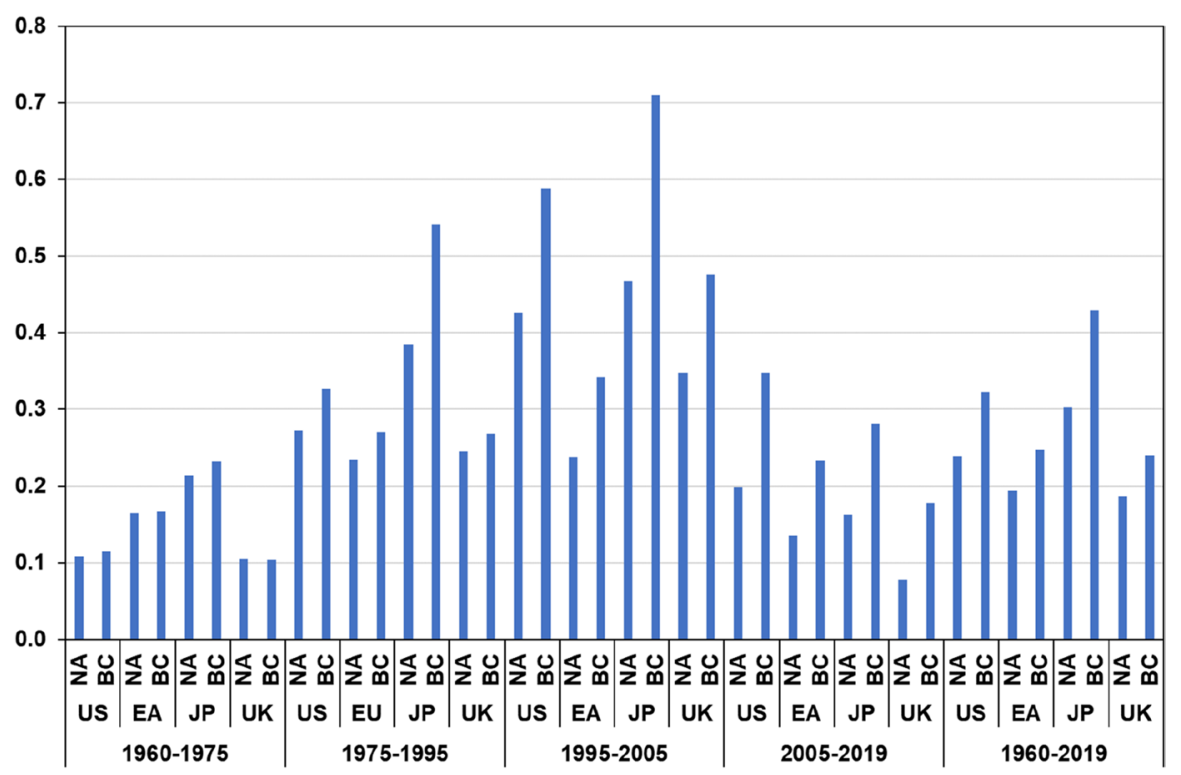

Fig. 8 ICT capital deepening contribution to labor productivity per hour growth, In pp Source: Authors' calculations. NA: ICT prices from US national accounts; BC: ICT prices from Byrne and Corrado (2016, 2017a; b)

it could affect the evaluation of the ICT capital deepening productivity impact and consequently the non-ICT capital deepening productivity impact.

Figure 8 represents the estimated contribution of ICT capital deepening to labor productivity growth in the US, the Euro Area, Japan and the UK, based on the ICT prices from US national accounts (NA-estimate thereafter) or from Byrne and Corrado (2016; 2017a; b) (BC-estimate). ${ }^{13}$ The gap between the two estimates depends on three factors: the gap in the average annual growth rate of ICT investment prices for each of the three ICT products; the share of each of the three ICT products in the total ICT capital deepening and the changes in these three shares.

Over the whole period 1960-2019, the BC-estimate is higher than the NA-estimate by about $20 \%$ in the UK, $30 \%$ in the US and the Euro Area and 40\% in Japan. And this gap is increasing over time. It is the smallest in the sub-period 1960-1975, where it is nil in the UK and equal to about 2\% in the Euro Area, 7\% in the US and 8\% in Japan. In contrast, it is the largest during in the sub-period 2005-2019, where it is equal to $70 \%$ to $80 \%$ in the US, the Euro Area and Japan and even slightly over 100\% in the UK.

Despite the fact that the gap between the two estimates is increasing over time, the ICT capital-deepening contribution to labor productivity growth is lower in 2005-2019 than in 1995-2005 according to both estimates. This implies that a possible mismeasurement of ICT investment prices would explain only some of the observed decrease in the contribution of ICT capital deepening to labor productivity

\footnotetext{
${ }^{13}$ Same calculations and complete growth accounting decomposition using prices from Byrne and Corrado (2016, 2017a, 2017b) are available, for all countries in our database, upon request from the authors.
} 
growth based on the NA-estimate. The gap is also accounted for by a smaller decrease in the ICT investment prices in 2005-2019 than in 1995-2005 for all ICT investment products as well as by a slowdown in ICT investment at current price. In both estimates, the contribution of ICT capital deepening to labor productivity growth is the highest during the decade 1995-2005 compared to the other sub-periods. In the four economic areas, the ICT capital deepening contribution to labor productivity growth is even lower in the sub-period 2005-2019 than in the sub-period 1975-1995 based on the NA-estimate. It is still the case for the BC-estimate, except in the US where the ICT capital deepening contribution is slightly higher in the 2005-2019 sub-period than in the 1975-1995 sub-period.

\section{Conclusion}

Growth accounting is the most widely used approach to measure the contribution of information and telecommunication technologies (ICTs) to productivity growth. This paper has contributed to the growth accounting literature by estimating the contribution of ICT capital and robots to labor productivity growth in 30 countries and the Euro Area over almost six decades (1960-2019), based on a new dataset developed for this purpose.

The main drivers of labor productivity growth over the whole period 1960-2019 period appear to be TFP, non-ICT and non-robot capital deepening, and education. We observe an exhaustion of the positive effect of education, related to the slowdown of the increase in the number of schooling years of the working age population (see Bergeaud et al. 2018). The overall contribution of ICT capital deepening is found out to be declining from the mid-2000s, although we do not estimate the ICT impact on TFP. The contribution of robots to productivity growth through the two channels (capital deepening and TFP) appears to be significant in Germany and Japan in the sub-period 1975-1995, in France and Italy in 1995-2005, and in several Eastern European countries in 2005-19.

Our findings confirm the slowdown in TFP in most countries from at least 1995 onwards, and from mid-2000s in the US. This slowdown is mainly explained in our growth accounting approach by a decrease in the contributions of the components 'others' in the capital deepening and the TFP productivity channels. While several contributions have recently addressed this issue (for examples, Van Ark, 2016; Andrews et al., 2016; Gordon and Sayed, 2020), further analysis appears necessary to explain the cause of such slowdown.

We are still waiting for a large productivity benefit from the Third Industrial Revolution: the digital one. We know from previous industrial revolutions that it may take decades to get a large productivity benefit at the global level from promising inventions and innovations. If we extrapolate that it could take a long time for the full impact of the digital revolution to be felt in productivity statistics at the global level. If this explanation is the right one, we could benefit in some years or decades from a dramatic productivity revival. The delay and size of this benefit will also depend on institutions, and in particular regulations, and some anticompetitive changes over the last two decades could have a detrimental 
impact (see, for instance, concerning the US, Philippon, 2019). Without enough benefit from the digital revolution, developed countries would face with difficulties the numerous challenges of the future. These challenges, which Gordon refers to as headwinds (see, for instance, among many papers, Gordon, 2015), include population aging, climate sustainability, the reduction of public debt and expectation of purchasing power increases. Moreover, without sufficient productivity growth to oil the wheels of the economy, the sustainability of the social systems and the high standard of living of developed countries would be threatened and the political risks to our democracies would inevitably increase.

\section{Appendix}

Results of growth accounting decomposition for some countries and the Euro Area $^{14}$, GDP growth (in \%) and contributions (in pp).

See Figures 9, 10, 11, 12, 13, 14, 15, 16 and 17.

\begin{tabular}{|c|c|c|c|c|c|}
\hline GDP growth (in \%) and contributions (in pp) & Period 1 & Period 2 & Period 3 & Period 4 & Period 5 \\
\hline United States & $1960 \quad 1975$ & $1975 \quad 1995$ & $1995 \quad 2005$ & $2005 \quad 2019$ & $1960 \quad 2019$ \\
\hline GDP (1) & 3,66 & 3,16 & 3,39 & 1,76 & 2,99 \\
\hline Hours (2) & 1,38 & 1,88 & 1,01 & 0,71 & 1,33 \\
\hline Productivity $(3)=(1)-(2)$ & 2,28 & 1,29 & 2,38 & 1,05 & 1,67 \\
\hline Capital deepening (4) & 0,67 & 0,25 & 0,58 & 0,40 & 0,45 \\
\hline ICT capital total $(5)=(6)+(7)+(8)$ & 0,11 & 0,27 & 0,43 & 0,20 & 0,24 \\
\hline Hardware (6) & 0,06 & 0,15 & 0,21 & 0,05 & 0,11 \\
\hline Software and databases (7) & 0,03 & 0,09 & 0,14 & 0,11 & 0,09 \\
\hline Telecommunication eqpt ( 8 ) & 0,03 & 0,04 & 0,07 & 0,04 & 0,04 \\
\hline Robots (9) & 0,00 & 0,01 & 0,03 & 0,03 & 0,02 \\
\hline Non ICT capital and non robots capital $(10)=(4)-(5)-(9)$ & 0,55 & $-0,03$ & 0,13 & 0,16 & 0,19 \\
\hline $\operatorname{TFP}(11)=(3)-(4)$ & 1,61 & 1,03 & 1,79 & 0,65 & 1,22 \\
\hline Education (12) & 0,45 & 0,27 & 0,20 & 0,17 & 0,28 \\
\hline Robotisation (13) & 0,01 & 0,03 & 0,08 & 0,10 & 0,05 \\
\hline Residual $(14)=(11)-(12)-(13)$ & 1,15 & 0,73 & 1,51 & 0,38 & 0,89 \\
\hline
\end{tabular}

Fig. 9 The US

\begin{tabular}{|c|c|c|c|c|c|}
\hline GDP growth (in \%) and contributions (in pp) & Period 1 & Period 2 & Period 3 & Period 4 & Period 5 \\
\hline Euro Area & $1960 \quad 1975$ & $1975 \quad 1995$ & $1995 \quad 2005$ & $2005 \quad 2019$ & $1960 \quad 2019$ \\
\hline GDP (1) & 4,60 & 2,44 & 2,12 & 1,09 & 2,61 \\
\hline Hours (2) & $-0,71$ & $-0,22$ & 0,93 & 0,37 & $-0,01$ \\
\hline Productivity (3) $=(1)-(2)$ & 5,31 & 2,66 & 1,19 & 0,72 & 2,63 \\
\hline Capital deepening (4) & 2,03 & 0,97 & 0,43 & 0,42 & 1,02 \\
\hline ICT capital total $(5)=(6)+(7)+(8)$ & 0,17 & 0,23 & 0,24 & 0,14 & 0,19 \\
\hline Hardware (6) & 0,11 & 0,12 & 0,11 & 0,03 & 0,09 \\
\hline Software and databases (7) & 0,03 & 0,09 & 0,10 & 0,09 & 0,08 \\
\hline Telecommunication eqpt ( 8 ) & 0,03 & 0,02 & 0,03 & 0,02 & 0,03 \\
\hline Robots (9) & 0,00 & 0,03 & 0,08 & 0,05 & 0,04 \\
\hline Non ICT capital and non robots capital $(10)=(4)-(5)-(9)$ & 1,86 & 0,71 & 0,11 & 0,24 & 0,79 \\
\hline $\operatorname{TFP}(11)=(3)-(4)$ & 3,28 & 1,69 & 0,77 & 0,30 & 1,61 \\
\hline Education (12) & 0,59 & 0,38 & 0,21 & 0,31 & 0,39 \\
\hline Robotisation (13) & 0,01 & 0,08 & 0,24 & 0,15 & 0,12 \\
\hline Residual $(14)=(11)-(12)-(13)$ & 2,68 & 1,23 & 0,32 & $-0,16$ & 1,10 \\
\hline
\end{tabular}

Fig. 10 Euro Area

${ }^{14}$ Same tables concerning other countries of our dataset are available upon request from the authors. 


\begin{tabular}{|c|c|c|c|c|c|}
\hline GDP growth (in \%) and contributions (in pp) & Period 1 & Period 2 & Period 3 & Period 4 & Period 5 \\
\hline United Kingdom & $1960 \quad 1975$ & 19751995 & $1995 \quad 2005$ & $2005 \quad 2019$ & 19602019 \\
\hline GDP (1) & 2,35 & 2,28 & 3,05 & 1,36 & 2,21 \\
\hline Hours (2) & $-0,70$ & $-0,23$ & 0,89 & 0,91 & 0,11 \\
\hline Productivity $(3)=(1)-(2)$ & 3,04 & 2,52 & 2,16 & 0,45 & 2,10 \\
\hline Capital deepening (4) & 1,69 & 0,79 & 0,41 & 0,32 & 0,84 \\
\hline ICT capital total $(5)=(6)+(7)+(8)$ & 0,11 & 0,24 & 0,35 & 0,08 & 0,19 \\
\hline Hardware (6) & 0,07 & 0,09 & 0,22 & 0,03 & 0,09 \\
\hline Software and databases (7) & 0,03 & 0,14 & 0,08 & 0,04 & 0,08 \\
\hline Telecommunication eqpt ( 8 ) & 0,00 & 0,01 & 0,05 & 0,01 & 0,01 \\
\hline Robots (9) & 0,00 & 0,01 & 0,01 & 0,01 & 0,01 \\
\hline Non ICT capital and non robots capital $(10)=(4)-(5)-(9)$ & 1,58 & 0,54 & 0,05 & 0,23 & 0,65 \\
\hline $\operatorname{TFP}(11)=(3)-(4)$ & 1,35 & 1,72 & 1,75 & 0,13 & 1,26 \\
\hline Education (12) & 0,76 & 0,42 & 0,06 & 0,10 & 0,37 \\
\hline Robotisation (13) & 0,00 & 0,03 & 0,04 & 0,02 & 0,02 \\
\hline Residual $(14)=(11)-(12)-(13)$ & 0,58 & 1,27 & 1,65 & 0,02 & 0,86 \\
\hline
\end{tabular}

Fig. 11 The UK

\begin{tabular}{|c|c|c|c|c|c|}
\hline GDP growth (in \%) and contributions (in pp) & Period 1 & Period 2 & Period 3 & Period 4 & Period 5 \\
\hline Japan & $1960 \quad 1975$ & $1975 \quad 1995$ & $1995 \quad 2005$ & $2005 \quad 2019$ & $1960 \quad 2019$ \\
\hline GDP (1) & 7,90 & 3,70 & 1,13 & 0,65 & 3,61 \\
\hline Hours (2) & 0,57 & 0,49 & $-0,75$ & $-0,14$ & 0,15 \\
\hline Productivity (3) $=(1)-(2)$ & 7,33 & 3,21 & 1,89 & 0,79 & 3,46 \\
\hline Capital deepening (4) & 3,40 & 1,58 & 1,92 & 0,42 & 1,82 \\
\hline ICT capital total $(5)=(6)+(7)+(8)$ & 0,22 & 0,39 & 0,47 & 0,16 & 0,30 \\
\hline Hardware (6) & 0,15 & 0,23 & 0,23 & 0,03 & 0,16 \\
\hline Software and databases (7) & 0,01 & 0,09 & 0,17 & 0,10 & 0,09 \\
\hline Telecommunication eqpt ( 8 ) & 0,06 & 0,07 & 0,06 & 0,03 & 0,06 \\
\hline Robots (9) & 0,01 & 0,21 & 0,01 & $-0,02$ & 0,06 \\
\hline Non ICT capital and non robots capital $(10)=(4)-(5)-(9)$ & 3,17 & 0,98 & 1,44 & 0,28 & 1,46 \\
\hline $\operatorname{TFP}(11)=(3)-(4)$ & 3,92 & 1,64 & $-0,03$ & 0,37 & 1,64 \\
\hline Education (12) & 0,42 & 0,32 & 0,37 & 0,22 & 0,33 \\
\hline Robotisation (13) & 0,04 & 0,66 & 0,02 & $-0,06$ & 0,20 \\
\hline Residual $(14)=(11)-(12)-(13)$ & 3,47 & 0,66 & $-0,43$ & 0,22 & 1,11 \\
\hline
\end{tabular}

Fig. 12 Japan

\begin{tabular}{|c|c|c|c|c|c|}
\hline GDP growth (in \%) and contributions (in pp) & Period 1 & Period 2 & Period 3 & Period 4 & Period 5 \\
\hline Canada & 19601975 & 19751995 & 19952005 & $2005 \quad 2019$ & $1960 \quad 2019$ \\
\hline GDP (1) & 4,66 & 2,67 & 3,24 & 1,75 & 3,05 \\
\hline Hours (2) & 2,24 & 1,53 & 1,68 & 0,86 & 1,58 \\
\hline Productivity $(3)=(1)-(2)$ & 2,42 & 1,14 & 1,56 & 0,89 & 1,48 \\
\hline Capital deepening (4) & 0,74 & 0,79 & 0,35 & 0,66 & 0,67 \\
\hline ICT capital total $(5)=(6)+(7)+(8)$ & 0,15 & 0,23 & 0,34 & 0,13 & 0,20 \\
\hline Hardware (6) & 0,11 & 0,13 & 0,20 & 0,04 & 0,12 \\
\hline Software and databases (7) & 0,01 & 0,07 & 0,09 & 0,07 & 0,06 \\
\hline Telecommunication eqpt (8) & 0,03 & 0,03 & 0,05 & 0,02 & 0,03 \\
\hline Robots (9) & 0,00 & 0,00 & 0,00 & 0,06 & 0,02 \\
\hline Non ICT capital and non robots capital $(10)=(4)-(5)-(9)$ & 0,59 & 0,56 & 0,01 & 0,47 & 0,45 \\
\hline $\operatorname{TFP}(11)=(3)-(4)$ & 1,67 & 0,35 & 1,20 & 0,23 & 0,80 \\
\hline Education (12) & 0,57 & 0,40 & 0,23 & 0,18 & 0,36 \\
\hline Robotisation (13) & 0,00 & 0,00 & 0,01 & 0,18 & 0,05 \\
\hline Residual $(14)=(11)-(12)-(13)$ & 1,11 & $-0,06$ & 0,96 & $-0,14$ & 0,39 \\
\hline
\end{tabular}

Fig. 13 Canada 


\begin{tabular}{|c|c|c|c|c|c|}
\hline GDP growth (in \%) and contributions (in pp) & Period 1 & Period 2 & Period 3 & Period 4 & Period 5 \\
\hline Germany & $1960 \quad 1975$ & $1975 \quad 1995$ & $1995 \quad 2005$ & $2005 \quad 2019$ & $1960 \quad 2019$ \\
\hline GDP (1) & 3,68 & 2,47 & 1,20 & 1,52 & 2,33 \\
\hline Hours (2) & $-1,41$ & $-0,42$ & $-0,67$ & 0,86 & $-0,41$ \\
\hline Productivity $(3)=(1)-(2)$ & 5,09 & 2,89 & 1,87 & 0,65 & 2,74 \\
\hline Capital deepening (4) & 2,16 & 0,96 & 0,80 & 0,23 & 1,07 \\
\hline ICT capital total $(5)=(6)+(7)+(8)$ & 0,19 & 0,24 & 0,26 & 0,07 & 0,19 \\
\hline Hardware (6) & 0,13 & 0,15 & 0,14 & 0,02 & 0,11 \\
\hline Software and databases (7) & 0,02 & 0,06 & 0,07 & 0,04 & 0,04 \\
\hline Telecommunication eqpt (8) & 0,04 & 0,03 & 0,05 & 0,01 & 0,03 \\
\hline Robots (9) & 0,01 & 0,05 & 0,17 & 0,10 & 0,08 \\
\hline Non ICT capital and non robots capital $(10)=(4)-(5)-(9)$ & 1,97 & 0,68 & 0,37 & 0,05 & 0,80 \\
\hline $\operatorname{TFP}(11)=(3)-(4)$ & 2,93 & 1,93 & 1,06 & 0,42 & 1,68 \\
\hline Education (12) & 0,69 & 0,20 & 0,03 & 0,01 & 0,25 \\
\hline Robotisation (13) & 0,02 & 0,15 & 0,53 & 0,32 & 0,24 \\
\hline Residual $(14)=(11)-(12)-(13)$ & 2,22 & 1,58 & 0,50 & 0,09 & 1,19 \\
\hline
\end{tabular}

Fig. 14 Germany

\begin{tabular}{|c|c|c|c|c|c|}
\hline GDP growth (in \%) and contributions (in pp) & Period 1 & Period 2 & Period 3 & Period 4 & Period 5 \\
\hline France & $1960 \quad 1975$ & $1975 \quad 1995$ & $1995 \quad 2005$ & $2005 \quad 2019$ & $1960 \quad 2019$ \\
\hline GDP (1) & 4,99 & 2,38 & 2,28 & 1,13 & 2,73 \\
\hline Hours (2) & $-0,18$ & $-0,18$ & 0,36 & 0,61 & 0,10 \\
\hline Productivity $(3)=(1)-(2)$ & 5,17 & 2,56 & 1,92 & 0,52 & 2,63 \\
\hline Capital deepening (4) & 1,80 & 1,00 & 0,53 & 0,41 & 0,98 \\
\hline ICT capital total $(5)=(6)+(7)+(8)$ & 0,15 & 0,24 & 0,26 & 0,19 & 0,21 \\
\hline Hardware (6) & 0,06 & 0,07 & 0,06 & 0,01 & 0,05 \\
\hline Software and databases (7) & 0,08 & 0,16 & 0,18 & 0,16 & 0,14 \\
\hline Telecommunication eqpt ( 8 ) & 0,01 & 0,01 & 0,02 & 0,02 & 0,01 \\
\hline Robots (9) & 0,00 & 0,02 & 0,04 & 0,01 & 0,02 \\
\hline Non ICT capital and non robots capital $(10)=(4)-(5)-(9)$ & 1,65 & 0,75 & 0,23 & 0,21 & 0,76 \\
\hline $\operatorname{TFP}(11)=(3)-(4)$ & 3,37 & 1,56 & 1,39 & 0,11 & 1,65 \\
\hline Education (12) & 0,72 & 0,25 & 0,26 & 0,45 & 0,42 \\
\hline Robotisation (13) & 0,01 & 0,06 & 0,13 & 0,04 & 0,06 \\
\hline Residual $(14)=(11)-(12)-(13)$ & 2,64 & 1,25 & 1,00 & $-0,38$ & 1,17 \\
\hline
\end{tabular}

Fig. 15 France

\begin{tabular}{|c|c|c|c|c|c|}
\hline GDP growth (in \%) and contributions (in pp) & Period 1 & Period 2 & Period 3 & Period 4 & Period 5 \\
\hline Italy & $1960 \quad 1975$ & $1975 \quad 1995$ & $1995 \quad 2005$ & $2005 \quad 2019$ & $1960 \quad 2019$ \\
\hline GDP (1) & 4,75 & 2,58 & 1,47 & $-0,06$ & 2,32 \\
\hline Hours (2) & $-1,13$ & $-0,03$ & 0,96 & $-0,09$ & $-0,15$ \\
\hline Productivity $(3)=(1)-(2)$ & 5,87 & 2,61 & 0,51 & 0,03 & 2,47 \\
\hline Capital deepening (4) & 2,53 & 1,04 & 0,37 & 0,39 & 1,15 \\
\hline ICT capital total $(5)=(6)+(7)+(8)$ & 0,13 & 0,23 & 0,20 & 0,11 & 0,17 \\
\hline Hardware (6) & 0,09 & 0,10 & 0,09 & 0,02 & 0,08 \\
\hline Software and databases (7) & 0,02 & 0,10 & 0,09 & 0,06 & 0,07 \\
\hline Telecommunication eqpt (8) & 0,02 & 0,02 & 0,02 & 0,02 & 0,02 \\
\hline Robots (9) & 0,00 & 0,04 & 0,09 & 0,03 & 0,04 \\
\hline Non ICT capital and non robots capital $(10)=(4)-(5)-(9)$ & 2,40 & 0,77 & 0,09 & 0,26 & 0,94 \\
\hline $\operatorname{TFP}(11)=(3)-(4)$ & 3,34 & 1,57 & 0,14 & $-0,36$ & 1,32 \\
\hline Education (12) & 0,58 & 0,61 & 0,46 & 0,41 & 0,53 \\
\hline Robotisation (13) & 0,01 & 0,11 & 0,27 & 0,10 & 0,12 \\
\hline Residual $(14)=(11)-(12)-(13)$ & 2,75 & 0,84 & $-0,59$ & $-0,86$ & 0,67 \\
\hline
\end{tabular}

Fig. 16 Italy 


\begin{tabular}{|c|c|c|c|c|c|}
\hline GDP growth (in \%) and contributions (in pp) & Period 1 & Period 2 & Period 3 & Period 4 & Period 5 \\
\hline Spain & $1960 \quad 1975$ & $1975 \quad 1995$ & $1995 \quad 2005$ & $2005 \quad 2019$ & $1960 \quad 2019$ \\
\hline GDP (1) & 6,55 & 2,30 & 3,62 & 1,05 & 3,31 \\
\hline Hours (2) & 0,13 & $-0,96$ & 4,25 & 0,07 & 0,44 \\
\hline Productivity $(3)=(1)-(2)$ & 6,42 & 3,26 & $-0,63$ & 0,99 & 2,87 \\
\hline Capital deepening (4) & 2,16 & 1,51 & $-0,13$ & 0,71 & 1,21 \\
\hline ICT capital total $(5)=(6)+(7)+(8)$ & 0,13 & 0,19 & 0,13 & 0,18 & 0,16 \\
\hline Hardware (6) & 0,09 & 0,10 & 0,07 & 0,03 & 0,08 \\
\hline Software and databases (7) & 0,01 & 0,06 & 0,06 & 0,12 & 0,06 \\
\hline Telecommunication eqpt (8) & 0,03 & 0,03 & 0,00 & 0,02 & 0,02 \\
\hline Robots (9) & 0,00 & 0,01 & 0,06 & 0,03 & 0,02 \\
\hline Non ICT capital and non robots capital $(10)=(4)-(5)-(9)$ & 2,03 & 1,31 & $-0,32$ & 0,51 & 1,02 \\
\hline $\operatorname{TFP}(11)=(3)-(4)$ & 4,26 & 1,76 & $-0,50$ & 0,27 & 1,66 \\
\hline Education (12) & 0,33 & 0,50 & 0,51 & 0,48 & 0,46 \\
\hline Robotisation (13) & 0,01 & 0,04 & 0,19 & 0,10 & 0,08 \\
\hline Residual $(14)=(11)-(12)-(13)$ & 3,92 & 1,21 & $-1,19$ & $-0,30$ & 1,13 \\
\hline
\end{tabular}

Fig. 17 Spain

Acknowledgements The authors thank David Byrne, Robert Gordon and Dan Sichel for their valuable comments as well as David Byrne and Carol Corrado for sharing their estimates of ICT deflators. They also thank three anonymous referees of the Journal who have helped to improve the paper. The authors are of course the only ones responsible for any error. The opinions expressed in this article are those of the authors and do not necessarily reflect those of the OECD or its member countries.

\section{References}

Acemoglu, D., and P. Restrepo. 2020. Robots and jobs: Evidence from US labor markets. Journal of Political Economy 128(6): 2188-2244.

Acemoglu, D., C. Lelarge, and P. Restrepo. 2020. Competing with robots: Firm-level evidence from France. American Economic Review, Papers and Proceedings 110: 383-388.

Aghion, P., P. Askenazy, R. Bourlès, G. Cette, and N. Dromel. 2009. Education, market rigidities and growth. Economics Letters 102(1): 62-65.

Ahmad, N., and P. Schreyer. 2016. Are GDP and productivity measures up to the challenges of the digital economy? International Productivity Monitor 30: 4-27.

Andrews, D., C. Criscuolo and P.N. Gal. 2016. The best versus the rest: The global productivity slowdown, divergence across firms and the role of public policy. OECD productivity working papers, 2016-05. Paris: OECD Publishing,

Autor, D. 2015. Why are there still so many jobs? The history and future of workplace automation. Journal of Economic Perspectives 29(3): 3-30.

Barro R. and J. Lee. (2010). A new data set of educational attainment in the world, 1950-2010. NBER Working Papers, Vol. 15902, National Bureau of Economic Research, Inc.

Bergeaud, A., G. Cette, and R. Lecat. 2016. Productivity trends in advanced countries between 1890 and 2012. The Review of Income and Wealth 62(3): 420-444.

Bergeaud, A., G. Cette, and R. Lecat. 2017. Total factor productivity in advanced countries: A long-term perspective. International Productivity Monitor 32: 6-24.

Bergeaud, A., G. Cette, and R. Lecat. 2018. The role of production factor quality and technology diffusion in twentieth-century productivity growth. Cliometrica 12(1): 61-97.

Bergeaud, A., G. Cette and R. Lecat. 2019. The circular relationship between productivity growth and real interest rates. Banque de France, Working Paper, Vol. 734.

Branstetter, L. and D. Sichel. 2017. The case for an American productivity revival. Peterson Institute for International Economics, Policy Brief, 17-26.

Brynjolfsson, E., and A. McAfee. 2014. The second machine age-work, progress, and prosperity in a time of brilliant technologies. New York: W. W. Norton \& Company.

Burda, M., and B. Severgnini. 2009. TFP growth in old and new Europe. Comparative Economic Studies 51: 447-466. 
Byrne, D., S. Oliner, and D. Sichel. 2013. Is the information technology revolution over? International Productivity Monitor 25: 20-36.

Byrne D. and C. Corrado. 2016. ICT Prices and ICT Services: What do they tell us about productivity and technology? Economics Program Working Paper, 16-05, May. New York: The Conference, Board.

Byrne MD, SD Oliner and DE Sichel (2015) How fast are semiconductor prices falling. NBER Working Papers, Vol. 21074.

Byrne, D., and C. Corrado. 2017a. ICT services and their prices: What do they tell us about productivity and technology? International Productivity Monitor 33: 150-181.

Byrne, D. and C. Corrado. 2017b. ICT prices and ICT services: What do they tell us about productivity and technology? Finance and Economics Discussion Series, Vol. 15. Washington, D.C: Board of the Federal Reserve System.

Cette, G., and J. Lopez. 2012. ICT demand behaviour: An international comparison. Economics of Innovation and New Technology 21(4): 397-410.

Cette, G., C. Clerc, and L. Bresson. 2015. Contribution of ICT diffusion to labour productivity growth: The United States, Canada, the Eurozone, and the United Kingdom. International Productivity Monitor 28: 81-88.

Cette, G., J. Lopez, and J. Mairesse. 2017. Upstream product marker regulations, ICT, R\&D and productivity. The Review of Income and Wealth 63: S68-S89.

Cette, G., J. Lopez, G. Presidente, and V. Spieza. 2019. Measuring 'indirect' investment in ICT in OECD countries. Economics of Innovation and New Technology 28(4): 348-364.

Cette, G., L. Koehl, and T. Philippon. 2020. Labor share. Economics Letters 188: 108979.

Colecchia, A., and P. Schreyer. 2002. ICT investment and economic growth in the 1990s: Is the United States a unique case? A comparative study of nine OECD countries. Review of Economic Dynamics 5(2): 408-442.

Corrado, C., C. Hulten, and D. Sichel. 2009. Intangible capital and economic growth. Review of Income and Wealth 55(3): 661-685.

Corrado, C., J. Haskel, M. Iommi, and C. Jona-Lasinio. 2020. Intangible capital, innovation, and productivity à la Jorgenson evidence from Europe and the United States. In Mesuring economic growth and productivity, ed. B. Fraumeny, 363-386. London: Elsevier, Academic Press.

Crépon, B., and T. Heckel. 2002. Computerization in France: An evaluation based on individual company data. Revue of Income and Wealth 48(1): 77-98.

David, P. 1990. The dynamo and the computer: An historical perspective on the modern productivity paradox. American Economic Review, Papers and Proceedings 80(2): 355-361.

Esfahani, M., J. Fernald and B. Hobijn. 2020. World productivity: 1996-2014. Federal Reserve Bank of San Francisco Working Paper 2020-17. https://doi.org/10.24148/wp2020-17.

Fernald, J. 2015. Productivity and potential output before, during, and after the great recession. NBER Macroeconomics Annual 29(1): 1-51.

Gordon, R. 2015. Secular stagnation: A supply-side view. American Economic Review 105(5): 54-59.

Gordon, R. 2016. The rise and fall of American growth. Princeton: Princeton University Press.

Gordon, R., and S. Hassan 2020. Transatlantic technologies: The role of ICT in the evolution of U.S. And European productivity growth. CEPR Discussion Paper No. DP15011, vol. 38, 50-80. Springer. https://ssrn.com/abstract $=3650126$. Also available in International Productivity Monitor.

Graetz G. and G. Michaels. (2015). Robots at work. CEPR, Discussion Paper No. 10477.

Graetz, G., and G. Michaels. 2018. Robots at work. The Review of Economics and Statistics 100(5): 753-768.

Guerrieri, P., M. Luciani, and V. Meliciani. 2011. The determinants of Investment in information and communication technologies. Economics of Innovation and New Technology 20(4): 387-403.

Inklaar, R., K. JÄger, M. O’Mahony, and B. van Ark. 2020. European productivity in the digital age: Evidence from EU KLEMS. In Measuring economic growth and productivity, ed. B. Fraumeny, 75-94. London: Elsevier, Academic Press.

Jordà, Ò., K. Knoll, D. Kuvshinov, M. Schularick, and A. Taylor. 2019. The rate of return on everything, 1870-2015. The Quarterly Journal of Economics 134(3): 1225-1298.

Jorgenson, D. 1963. Capital theory and investment behavior. The American Economic Review 53(2): 247-259. 
Jorgenson, D. 2001. Information technology and the US economy. The American Economic Review 91(1): 1-32.

Jorgenson, D.W., and K.J. Stiroh. 2000. Raising the speed limit: US economic growth in the information age. Brookings Papers on Economic Activity, Economic Studies Program, the Brookings Institution 31(1): 125-236.

Jorgenson, D., M. Ho, and K. Stiroh. 2006. Potential growth of the US economy: Will the productivity resurgence continue? Business Economy 41: 7-16.

Jorgenson, D., M. Ho, and K. Stiroh. 2008. A retrospective Look at the U.S. productivity growth resurgence. Journal of Economic Perspectives 22(1): 3-24.

Krueger, A., and M. Lindahl. 2001. Education for growth: Why and for whom? Journal of Economic Literature, American Economic Association 39(4): 1101-1136.

O’Mahony, M., and M. Vecchi. 2005. Quantifying the Impact of ICT on Output Growth: A heterogeneous dymamic panel approach. Economica 72(288): 615-633.

OECD. 2001. Measuring productivity. Paris: OECD Publishing.

OECD. 2009. Measuring capital: OECD manual, 2nd ed. Paris: OECD Publishing.

OECD. 2018. Main economic indicators. Paris: OECD Publishing.

OECD. 2019. OECD compendium of productivity indicators 2019. Paris: OECD Publishing.

OECD. 2020. National accounts of OECD countries, Vol. 2, detailed tables. https://doi.org/10.1787/ $2221433 x$.

Oliner, S., and D. Sichel. 2000. The resurgence of growth in the late 1990s: Is information technology the story? Journal of Economic Perspectives 14: 3-22.

Oliner, S., and D. Sichel. 2002. Information technology and productivity: Where are we now and where are we going? Federal Reserve Bank of Atlanta Review 87(3): 15-44.

Oulton, N. 2002. ICT and productivity growth in the United Kingdom. Oxford Review of Economic Policy 18(3): 363-379.

Philippon, T. 2019. The great reversal: How America gave up on free markets. Cambridge: Harvard University Press.

Schreyer, P. 2000. The contribution of information and communication technology to output growth: a study on the G7 countries. OECD Science, Technology and Industry Working Papers 2000/2. OECD.

Solow, R. 1956. A contribution to the theory of growth. Quarterly Journal of Economics 70(1): 65-94.

Solow, R. 1957. Technical change and aggregate production function. Review of Economics and Statistics 39(3): 312-320.

Solow, R. 1959. Investment and technical change. In Mathematical methods in the social sciences. Stanford.

Solow, R. 1962. technical progress, capital formation, and economic growth. The American Economic Review 52(2): 76-86.

Soto, M. 2002. Rediscovering education in growth regressions. OECD development centre working papers 202. OECD Publishing.

Spiezia, V. 2012. ICT investments and productivity: Measuring the contribution of ICTS to growth. OECD Journal: Economic Studies. https://doi.org/10.1787/eco_studies-2012-5k8xdhj4tv0t.

Syverson, C. 2016. Challenges to mismeasurement explanations for the U.S. productivity slowdown. NBER Working Papers, No. 21974. https://www.nber.org/papers/w21974

The Conference Board. 2020. Total Economy Database ${ }^{\mathrm{TM}}$, July 2020. https://conference-board.org/data/ economydatabase/total-economy-database-productivity.

Timmer, M., R. Inklaar, M. O’Mahony, and B. van Ark. 2010. Economic growth in Europe: A comparative industry perspective. Cambridge: Cambridge University Press.

Timmer, M., R. Inklaar, M. O’Mahony, and B. Van Ark. 2011. Productivity and economic growth in Europe: A comparative industry perspective. International Productivity Monitor 21: 3-23.

Van Ark, B. 2016. The productivity paradox of the new digital economy. International Productivity Monitor 31: 3-18.

Van Ark B., J. Melka, N. Mulder, M. Timmer and G. Ypma. 2002. ICT Investment and Growth Accounts for the European Union, 1980-2000. Final report on ICT and Growth Accounting prepared for the DG Economics and Finance of the European Commission. Brussels.

Van Ark, B., M. O'Mahony, and M. Timmer. 2008. The productivity gap between Europe and the United States: Trends and Causes. Journal of Economic Perspectives 22(1): 25-44. 
Van Leeuwen, B., and J. van Leeuwen-Li. 2014. Education since 1820. In How was life?: Global wellbeing since 1820, ed. J.L. van Zanden, et al., 88-101. Paris: OECD Publishing.

Vonyó, T., and A. Klein. 2017. Why did socialist economies fail? The role of factor inputs reconsidered. The Economic History Review 72(1): 317-345.

Publisher's Note Springer Nature remains neutral with regard to jurisdictional claims in published maps and institutional affiliations. 